\title{
DOI: 10.22620/agrisci.2021.31.001 \\ FEATURES OF THE TEMPERATURE REGIME EFFECT ON THE DURATION OF THE CROPS VEGETATION PERIOD IN SOUTHERN UKRAINE
}

\author{
Kalinka Kouzmova1, Anna A. Ilina², Anatoliy N. Polevoy ${ }^{2 *}$, \\ ${ }^{1}$ Agricultural University - Plovdiv \\ ${ }^{2}$ Odessa State Environmental University, \\ 15 Lvivska Street, Odessa, 65106, UKRAINE \\ * E-mail: apolevoy@te.net.ua
}

\begin{abstract}
When modeling the prognostic changes in the temperature regime over the territory of Ukraine, the data of the research project for modeling the regional climate and assessing the consequences of its change (CORDEX) were used. The climate projection structure is based on a series of global climatic models (GCM) developed within the framework of CMIP5 project. The influence of the temperature factors on passing the phenological phases and oats yield in the South of Ukraine, implementing the RCP4.5 and RCP8.5 climate scenarios and comparing them with the long-term data is analyzed. As a result of the analysis of the changes in the temperature regime it was revealed that it will be warming the plants vegetation period. The probable change in the oats yield in the southern part of Ukraine under the conditions of climate change using the crop formation model was considered. It is assumed that by 2050 the timing of sowing and germinating the seedlings will be shifted to an earlier date, and the oats yield will increase by 1.26-1.32 times.
\end{abstract}

Key words: climate change, modeling, agroclimatic resources, vegetation period, yield

\section{INTRODUCTION}

The global climate change and the changes in the bioclimatic potential of the regions are of great scientific and practical importance to determining the compliance of climatic conditions with the crops requirements. Crops heat supply shows a quantitative characteristic of the thermal resources compliance degree and the plants' need for warmth. Since the temperature factor is crucial for the growth, each plant species has a certain temperature range - minimum (the germination process can already begin), optimal (the best temperature for germinating) and maximum temperature - the upper limit at which seeds can still germinate (Hatfield et al., 2011).

In modeling the prognostic changes of the temperature regime over the territory of Ukraine, the data of the research project for modeling the regional climate and assessing the consequences of its change (CORDEX Coordinated Regional Climate Downscaling Experiment), performed by the World Climate Research Program (2014) were used. The climate projection structure in the CORDEX project is based on a series of global climatic models (GCM) developed within the framework of the CMIP5 project. The study applied calculations using the RACMO2 regional climate model for baseline scenarios of medium and high levels of greenhouse gas emissions RCP4.5 and RCP8.5 (Jacob et al., 2014; Van Vuuren et al., 2011).

\section{MATERIALS AND METHODS}

Ukraine is characterized by zonation, directly related to the natural features of the territory. The landscapes of the steppe zone, which lies to the south of the Forest-Steppe and extends to the Azov-Black Sea coast and the 
Crimean Mountains, was formed due to a relatively high amount of heat with a negative moisture balance. According to the landscape structure, humidification conditions and thermal resources, the steppe zone is divided into three subzones: northern steppe, middle steppe and southern steppe (dry steppe) (Hutsuliak et al., 2015). The change in the thermal regime observed in Ukraine in recent decades has significantly affected the development and formation of crop yields and has caused the fluctuations in crops gross harvests (Balabukh \& Malytska, 2017; Stepanenko \& Polevoy, 2015; Polevoy et al., 2007).

The scenarios (RCP4.5 and RCP8.5) (Dankers \& Hiedere, 2008), namely the Representative Concentration Pathways (RCP), are used for calculating the climate and assessing the changes in the heat resources of the crops vegetative period (for example, oats). The data from 12 meteorological stations of the Steppe zone of Ukraine (the Donetsk, Dnipropetrovsk, Mykolaiv, Odesa, Zaporizhia, Kherson regions and the Autonomous Republic of Crimea) for two periods: 1986-2015 (longterm averages) and 2021-2050 were used to determine the thermal regime indicators. In this paper in order to assess the agroclimatic conditions of oats cultivation, a characteristic of the growing season temperature regime such as the duration of the period with air temperatures above $0,5,10,15^{\circ} \mathrm{C}$ was calculated and presented. Assessing the climate change impact on the oat crop productivity was carried out using the yield formation model (Polevoy et al., 2007), adapted to this crop.

\section{RESULTS AND DISCUSSION}

The informative characteristic of the territory thermal resources is the amount of average daily air temperatures for the time interval with a certain temperature. In agroclimatology, the need for cultures and varieties in heat is estimated by a sum of active, effective, biological, bioclimatic temperatures (Mishchenko, 2009).

Usually thermal resources and the plants' need in heat are expressed by an average long-term sum of average daily air temperatures for the period when their value exceeds $+10^{\circ} \mathrm{C}$, i.e. the sum of active temperatures for the period from sowing to plant maturation. To fully characterize the crops heat supply the sums of active air temperatures above $5^{\circ} \mathrm{C}, 10^{\circ} \mathrm{C}$ and $15^{\circ} \mathrm{C}$ were calculated and analyzed.

The obtained simulation results show that the sums of active temperatures within the North-steppe subzone will decrease at all stations. Thus, the sum of active temperatures above $0^{\circ} \mathrm{C}$ will decrease by about $15-20 \%$. There will also be a decrease in temperatures above 5,10 and $15^{\circ} \mathrm{C}$ : the difference in both scenarios will be approximately $10 \%$. On average for a long-term period (1986-205) in the North-Steppe subzone, the average air temperature in January is $-3.6^{\circ} \mathrm{C}$, and in July $22.4^{\circ} \mathrm{C}$. In the time interval there is a tendency of lowering temperature in the cold (January) and summer (July) periods in the Donetsk region. The territory of the Odesa and Mykolayiv regions in both climate change scenarios is marked by an increase in the temperature in January by an average of $1^{\circ} \mathrm{C}$ and a decrease in the air temperature in July - by $0.5^{\circ} \mathrm{C}$ in comparison with the average long-term data. The amplitude of air temperature fluctuations will decrease (except for the Donetsk region, the RCP 8.5 scenario) by an average of $1.2^{\circ} \mathrm{C}$.

On the territory of the Central Steppe subzone almost at all meteorological stations of the regions that are a part of the subzone, there is a significant decrease in the sum of active air temperatures above $5^{\circ} \mathrm{C}, 10^{\circ} \mathrm{C}$ and $15^{\circ} \mathrm{C}$ in both RCP 4.5 and RCP 8.5. The exceptions are the Zaporizhia and Odesa regions, where under the RCP 8.5 scenario there will be a slight increase in the sum of active temperatures above $5^{\circ} \mathrm{C}$, $10^{\circ} \mathrm{C}$ and $15^{\circ} \mathrm{C}$. The average monthly temperature in January will increase by $1.5^{\circ} \mathrm{C}$, 
and for August it will hardly change. The annual amplitude of the average temperature of the coldest month (January) and the warmest month (August) for the forecast period will decrease by $1.5-2^{\circ} \mathrm{C}$.

The research revealed that for the territory of the South-Steppe subzone of Ukraine in 2021-2050 the sum of temperatures above $0^{\circ} \mathrm{C}, 5^{\circ} \mathrm{C}, 10^{\circ} \mathrm{C}$ and $15^{\circ} \mathrm{C}$ is expected to decrease, namely on the territory of the Kherson (the Askania-Nova station) and Odesa (the Odessa station) regions in both scenarios. In the near future, the sum of temperatures above $0^{\circ} \mathrm{C}$ in the Crimea will increase from $3990^{\circ} \mathrm{C}$ to $4111^{\circ} \mathrm{C}$ (according to the RCP4.5 scenario) and to $4214^{\circ} \mathrm{C}$ (according to the RCP8.5 scenario). At the same time, there will be a significant reduction in the sum of temperatures above $15^{\circ} \mathrm{C}$ : the difference will be $-126^{\circ} \mathrm{C}$ in the $\mathrm{RCP} 4.5$ scenario and $-30^{\circ} \mathrm{C}$ in the RCP8.5 scenario.

Our analysis shows that January will be $2{ }^{\circ} \mathrm{C}$ warmer for the period 2021-2050, and July will be $0.3^{\circ} \mathrm{C}$ cooler. One of the main characteristics of the crop growth conditions during the growing season is the duration of the period with a stable air temperature above + $5^{\circ} \mathrm{C}$. To visualize and give a general characteristic of the vegetation period heat supply on the investigated territory the scheme maps of the spatial distribution of the total active air temperatures above $5^{\circ} \mathrm{C}$ were constructed (Fig. 1, 2).

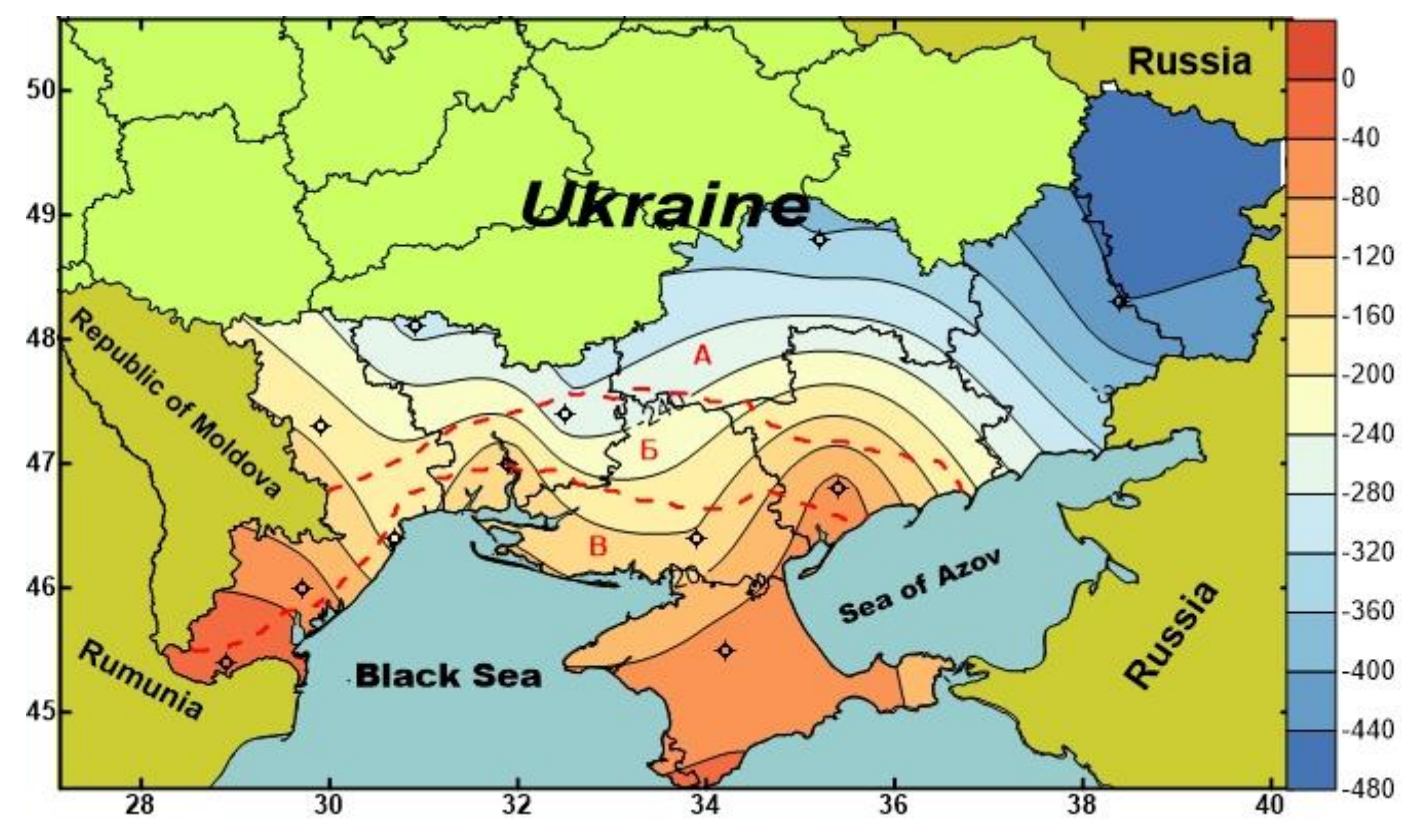

A - the North-Steppe subzone, B - the Central-Steppe subzone, C - the South-Steppe subzone

Fig. 1. A map of the difference between the sums of active air temperatures above $5^{\circ} \mathrm{C}$ in the South of Ukraine according to the scenario RCP 4.5

As can be seen from the figures, in the study area, the difference in the sum of active air temperatures above $5^{\circ} \mathrm{C}$ increases from the South Steppe subzone to the North Steppe subzone from $-5^{\circ} \mathrm{C}$ (the Izmail station in the Odessa region) to $450^{\circ} \mathrm{C}$ (the Debaltseve station in the Donetsk region).

Figure 2 shows that the spatial distribution of the difference in the sum of active air temperatures in the steppe zone of Ukraine under the climate scenario RCP 8.5 is characterized by an increase in temperature in the south and southeast to $150^{\circ} \mathrm{C}$ and above, thereby accelerate the plants phenological phases. 


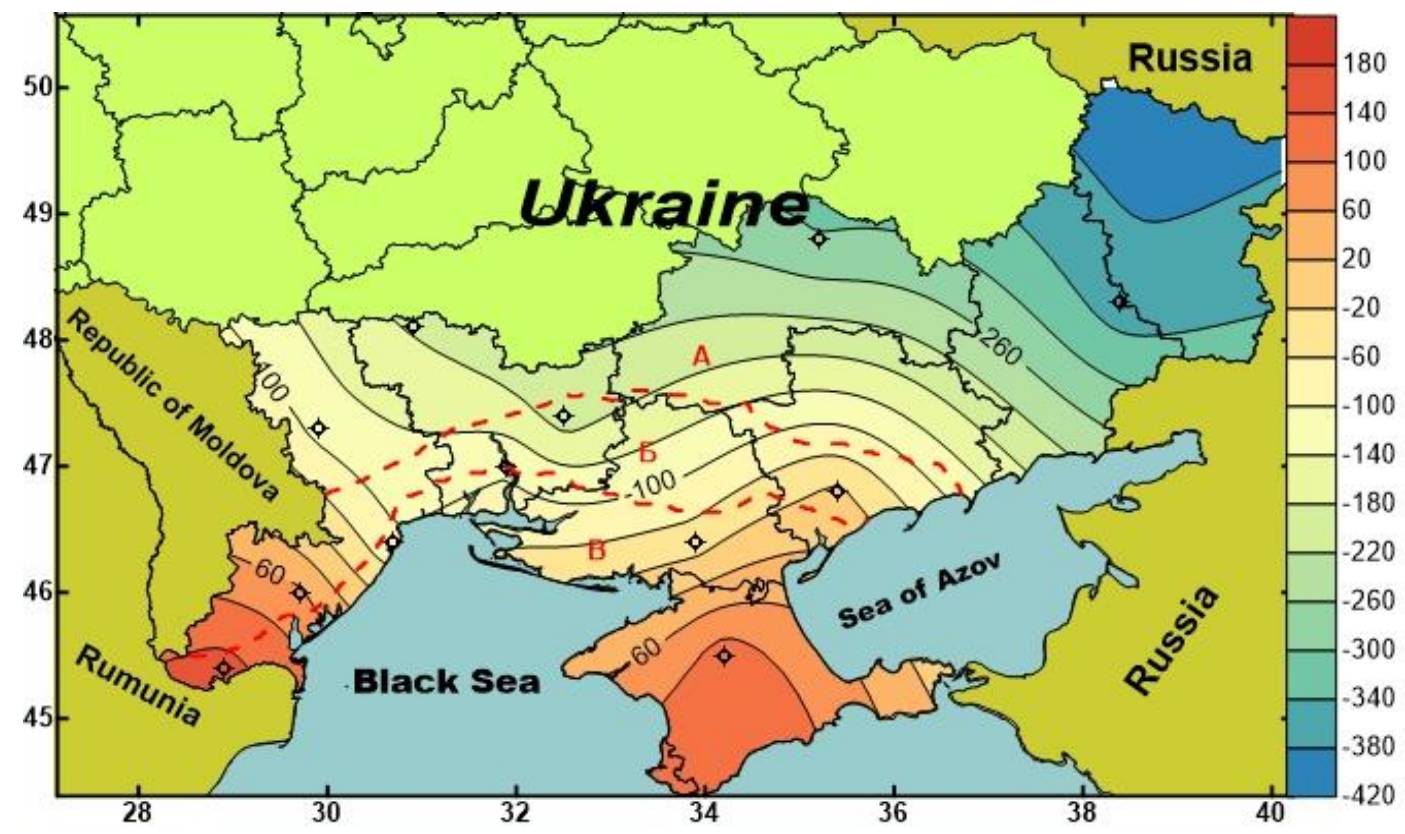

A - the North-Steppe subzone, B - the Central-Steppe subzone, C - the South-Steppe subzone

Fig. 2. A map of the difference between the sums of active air temperatures above $5^{\circ} \mathrm{C}$ in the South of Ukraine according to the scenario RCP 8.5

The studies have shown that the differences in the amounts of active temperatures will vary across the territory - its values will increase from the north to the south. The map shows that under the climate change condition for the period from 2021-2050 there will be an increase in the difference of air temperatures above $5^{\circ} \mathrm{C}$ in the South-steppe subzone (the Odessa, Kherson region and the Autonomous Republic of Crimea), which will be the average of $130-180^{\circ} \mathrm{C}$. The smallest values of the temperature difference will be observed in the Dnipropetrovsk and Donetsk (the North Steppe subzone) regions and on average will be minus $250-350^{\circ} \mathrm{C}$.

The sowing date is very important. The optimal sowing dates of early grain crops are the maximum early dates when the physical maturity of the soil comes. Delay in sowing significantly reduces the yield. When sowing spring crops at different times, different abiotic conditions are modeled, i.e. air temperatures, the sum of positive temperatures, a day duration, precipitation, etc. Delay in the date of sowing leads to a late plant development, which complicates harvesting and reduces the grain sowing quality («Development phases of oats», 2014).

Forecasting the dates of plants phenological phases is one of the main types of the required agrometeorological information. Phenological forecasts based on calculating the amounts of effective temperatures showed when implementing the scenario conditions, the oats vegetation will come in an earlier date with some time shift towards early spring (Table 1 ).

Thus, for the Northern subzone the sowing date will take place earlier by $15-16$ days, for the Central subzone - 5-6 days and for the Southern subzone - 3-4 days. This will cause a shift in the timing of oats seedlings. It will be the largest for the Northern subzone (14-15 days), insignificant (2-3 days) for the Central subzone and the terms of germination in the Southern subzone will shift moderately (for 7-6 days). The phase of inflorescence emergence in the Northern and Southern subzones will occur almost in the usual time, in the Central subzone - 5-6 days later than in a long time. The duration of the entire growing season (seedlings - dough development) in all subzones of the Steppe zone of Ukraine will increase. Due to the climate 
change the changes in the temperature conditions of the oats vegetation will lead to changing the crops photosynthetic activity and, as a consequence, to changes in forming the crop mass.

Table 1. The phases of oats development in the South of Ukraine

\begin{tabular}{|c|c|c|c|c|c|c|}
\hline \multirow[b]{2}{*}{ Subzone } & \multirow[b]{2}{*}{$\begin{array}{l}\text { Periods, } \\
\text { years }\end{array}$} & \multirow[b]{2}{*}{$\begin{array}{c}\text { Date of } \\
\text { sowing }\end{array}$} & \multicolumn{3}{|c|}{ Date of development phases } & \multirow{2}{*}{$\begin{array}{l}\text { Duration of } \\
\text { the growing } \\
\text { season, days }\end{array}$} \\
\hline & & & seedlings & $\begin{array}{c}\text { Inflorescence } \\
\text { emergence }\end{array}$ & \begin{tabular}{|c|} 
Dough \\
Development
\end{tabular} & \\
\hline \multirow[t]{5}{*}{ North } & $1986-2015$ & 07.04 & 21.04 & 09.06 & 07.07 & 78 \\
\hline & RCP4.5(2021-2050) & 22.03 & 6.04 & 09.06 & 07.07 & 93 \\
\hline & Difference & -16 & -15 & 0 & 0 & +25 \\
\hline & RCP8.5 (2021-2050) & 21.03 & 05.04 & 08.06 & 06.07 & 92 \\
\hline & Difference & -15 & -14 & -1 & -1 & +14 \\
\hline \multirow[t]{5}{*}{ Central } & $1986-2015$ & 29.03 & 13.04 & 03.06 & 01.07 & 79 \\
\hline & RCP4.5 (2021-2050) & 23.03 & 11.04 & 09.06 & 08.07 & 88 \\
\hline & Difference & -6 & -2 & +6 & +7 & +9 \\
\hline & RCP8.5 (2021-2050) & 24.03 & 10.04 & 08.06 & 07.07 & 88 \\
\hline & Difference & -5 & -3 & +5 & +6 & +9 \\
\hline \multirow[t]{5}{*}{ South } & $1986-2015$ & 23.03 & 11.04 & 03.06 & 29.06 & 98 \\
\hline & RCP4.5 (2021-2050) & 19.03 & 04.04 & 02.06 & 04.07 & 91 \\
\hline & Difference & -4 & -7 & -1 & +5 & -7 \\
\hline & RCP8.5( 2021-2050) & 20.03 & 05.04 & 04.06. & 06.07 & 92 \\
\hline & Difference & -3 & -8 & +1 & +7 & -6 \\
\hline
\end{tabular}

According to the climatic scenarios at earlier terms of sowing compared to the average long-term seeding time on the territory of all subzones of the Steppe zone the yield will be 1,26-1,32 times higher (Fig. 3).

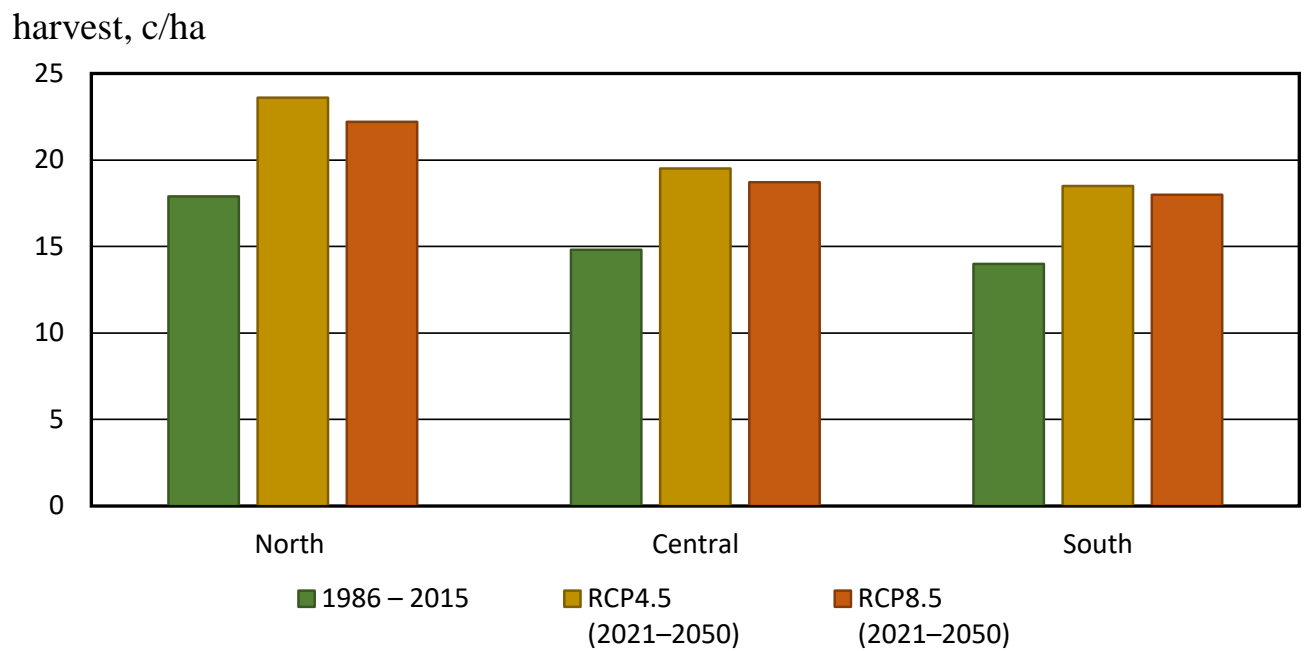

Fig. 3. The expected oats yield (c/ha) in the steppe zone of Ukraine according to the RCP4.5 scenario

As shown in the Figure, when implementing the RCP4.5 scenario, the
Figure 3 shows a level of the yield being expected implementing the RCP4.5 and RCP8.5 climate scenarios compared to the baseline data. 
central part they will range from 19.5 to $20.2 \mathrm{c} /$ ha, and in the southern part they will be from 16.7 to $18.8 \mathrm{~kg}$ / ha. The maximum yield values will be observed in the north of the Steppe zone and they will be 20.9-22.1 c / ha. The level of yield will be slightly lower in the central part of the Steppe zone, in the southern part it will also be lower and will be $15.5-17.9 \mathrm{c} / \mathrm{ha}$.

\section{CONCLUSION}

As a result of the analysis of the changes in the temperature regime it was revealed that it will be warming the plants vegetation period. The timing of sowing and germination will be shifted to an earlier date, which will allow using the moisture accumulated during the winter more efficiently. When implementing the climatic scenarios the changes in agro-climatic conditions will lead to the changes in oats crop photosynthetic activity: there will be an increase in the relative leaf area, the total plant mass, a crop photosynthetic potential during the growing season. It has been defined that the level of expected oats yields under the implementation of the RCP4.5 and RCP8.5 climatic scenarios and early sowing dates will be higher than those obtained under the average long-term conditions.

\section{REFERENCES}

AGRO-portal.su. 2014-2017. Development phases of oats. Retrieved from: [http://agro-portal.su/oves/2594-fazyrazvitiya-ovsa.html]. Accessed: 10.04.2021.

Balabukh, V., Malytska, L. (2017). Features of the thermal regime of Ukraine in the conditions of climate change. Geoinformatics Journal, 4(64): 5 - 20. (in Ukrainian)

Dankers, R., Hiedere, R. (2008). Extreme Temperatures and Precipitation in Europe: Analysis of a High-Resolution Climate. Change Scenario. European
Commission Joint Research Centre Institute for Environment and Sustainability. Luxembourg, 67 p.

Hatfield, J., Boote, K. , Kimball, B., Ziska, L., Izaurralde, R., Ort, D., Thomson, A., Wolfe, D. (2011). Climate impacts on agriculture: implications for crop production. - Agronomy Journal, 103(1): 351-370. doi: 10.2134/agronj2010.0303.

Hutsuliak, V., Maksymenko, N., Dudar, T. (2015). Landscape ecology. Kharkov, 284 p. (in Ukrainian).

Jacob, D., Petersen, J., Eggert, B., Alias, A., Christensen , O., Bouwer, L., Braun, A., Colette, A., Déqué, M. et al. (2014). EURO-CORDEX: new high resolution climate change projections for European impact research. Regional Environmental Change, 14(2): 563-578. doi: 10.1007/s10113-013-0499-2.

Meinshausen, M., Nakicenovic, N., Smith, S. and Rose, S (2011). The representative concentration pathways: an overview. Climatic Change, 109(1): 5-31. doi: 10.1007/s10584-011-0148-z

Polevoy, A., Kulbida, N., Adamenko, T., Trofimova, I. (2007). Modelling of influence of changes of a climate on agroclimatic conditions of cultivation and photosynthetic productivity of a winter wheat in Ukraine. Ukranian hydrometeorological journal, 2: 76-91. (in Ukrainian).

Stepanenko, S., Polevoy, A. (2015). Climatic changes and their impact on the spheres of the Ukrainian economy. Odesa, $518 \mathrm{p}$. (in Ukrainian).

Van Vuuren, D., Edmonds, J., Kainuma, M., Riahi, K., Thomson, A., Hibbard, K., Hurtt, G., Kram, T., Krey, V., Lamarque, J., Masui, T.,

Mishchenko, Z. (2009). Agroclimatology. Kiev, 512 p. (in Ukrainian). 